\title{
Synthesis and evaluation of anti-inflammatory, analgesic, ulcerogenic and lipid peroxidation properties of ibuprofen derivatives
}

MOHAMMAD AMIR* SHIKHA KUMAR

Department of Pharmaceutical Chemistry Faculty of Pharmacy

Hamdard University

New Delhi-110062, India
Accepted November 11, 2006
In order to reduce the ulcerogenic effect of ibuprofen, its carboxylic group has been converted into 5-membered heterocyclic rings. Various 1,3,4-oxadiazoles (3-8, 16-21), 1,2,4-triazoles (22-27), 1,3,4-thiadiazoles (28-30), and 1,2,4-triazine (9) derivatives of ibuprofen were prepared by cyclization of 2-(4-i-butylphenyl) propionic acid hydrazide (2) and $N^{1}$-[2-(4-i-butylphenyl)-propionyl]- $N^{4}$-alkyl/aryl-thiosemicarbazides (10-15) under various reaction conditions. The cyclized derivatives were screened for their anti-inflammatory activity by the carrageenan induced rat paw edema method and showed 50 to $86 \%$ inhibition, whereas the standard drug ibuprofen showed $92 \%$ inhibition at the same oral dose. Five compounds, 7, 16, 18, 22 and 30 that showed more than $80 \%$ anti-inflammatory activity were selected to study their analgesic, ulcerogenic and lipid peroxidation activities. All the tested compounds showed a significant reduction in ulcerogenic activity compared to ibuprofen through the severity index 0.5 to 0.8 , vs. ibuprofen 1.8 . The compounds, that showed less ulcerogenic effect also produced less malondialdehyde content in gastric mucosa, which is one of the end products of lipid peroxidation. The results of biological studies showed that oxadiazole derivative $\mathbf{1 6}$ as the lead molecule with maximum anti-inflammatory, analgesic and minimum ulcerogenic and lipid peroxidation activities.

Keywords: ibuprofen derivatives, anti-inflammatory activity, ulcerogenicity, lipid peroxidation

Currently available non-steroidal anti-inflammatory drugs (NSAIDs) like ibuprofen, diclofenac, indomethacin and flurbiprofen exhibit gastric toxicity. Long-term use of these drugs has been associated with gastro-intestinal (GI) ulceration, bleeding and nephrotoxicity (1). The GI damage from NSAIDs is generally attributed to two factors, local

\footnotetext{
*Correspondence, e-mail: mamir_s2003@yahoo.co.in
} 
irritation by the carboxylic acid moiety, common to most NSAIDs (topical effect) and decreased tissue prostaglandin production, which undermines the physiological role of cytoprotective prostaglandins in maintaining the GI health and homeostasis $(2,3)$. The pharmacological activity of NSAIDs is related to the suppression of prostaglandin biosynthesis from arachidonic acid by inhibiting cyclooxygenases (COXs) $(2,4)$. Chronic use of NSAIDs, including ibuprofen, may elicit appreciable GI toxicity (5); therefore, synthetic approaches based upon NSAIDs chemical modification have been undertaken with the aim of improving the NSAID safety profile. Studies described that the derivatization of the carboxylate function of representative NSAIDs, resulted in an increased anti-inflammatory activity with reduced ulcerogenic effect $(6,7)$. Furthermore, certain compounds bearing 1,3,4-oxadiazole/thiadiazole and 1,2,4-triazole nucleus have been reported to possess significant anti-inflammatory activity (8-11). In our attempt to discover new and useful agents for treating inflammatory diseases, we have replaced the carboxylic acid group of ibuprofen with additional heterocycles, which have been found to possess an interesting profile of anti-inflammatory activity with significant reduction of their ulcerogenic effect. The heterocycles reported here are 1,3,4-oxadiazoles, 1,2,4-triazoles, 1,3,4-thiadiazoles and 1,2,4-triazine. These compounds were evaluated for their ability to provide protection against the carrageenin induced rat paw edema. A few selected compounds were also screened for analgesic, ulcerogenic and lipid peroxidation activities.

\section{EXPERIMENTAL}

Melting points were measured in open capillary tubes and are uncorrected. IR $(\mathrm{KBr})$ spectra were recorded on a Nicolet, 5PC FT-IR spectrometer (Browser Morner, USA) and ${ }^{1} \mathrm{H}$ NMR spectra on a Bruker DRX-300 FT NMR (Bruker, Germany) spectrophotometer using TMS as internal reference (chemical shift in $\delta, \mathrm{ppm}$ ). Mass spectra were recorded on a Jeol-JMS-D-300 mass spectrometer (70 eV) (Jeol, Japan). Purity of the compounds was checked on silica gel $G$ plates using iodine vapours as visualizing agents. 2-(4-iButylphenyl)propionic acid (ibuprofen) was procured from Ace laboratories, India as a gift sample. All reagents used in the present work were of analytical grade.

Ethyl-[2-(4-i-butylphenyl) propionate] (1) was prepared by the procedure given in literature (12). 2-(4-i-Butylphenyl) propionic acid hydrazide (2) was prepared by the reported procedure (9).

The synthetic pathway is given in Scheme 1 and characterization data of compounds are given in Table I. Satisfactory analysis for $\mathrm{C}, \mathrm{H}, \mathrm{N}$ was obtained for all the compounds within $\pm 0.4 \%$ of the theoretical values.

\section{Syntheses}

5-[2-(4-i-Butylphenyl)ethyl]-2-mercapto-1,3,4-oxadiazole (3). - A mixture of 2 (0.005 mol), $\mathrm{KOH}(0.005 \mathrm{~mol})$ and carbon disulphide $(5 \mathrm{~mL})$ in ethanol $(50 \mathrm{~mL})$ was refluxed on a steam bath for $12 \mathrm{~h}$. The solution was then concentrated, cooled and acidified with diluted $\mathrm{HCl}$. The solid mass that precipitated was filtered, washed with ethanol, dried and recrystallized from ethanol. 

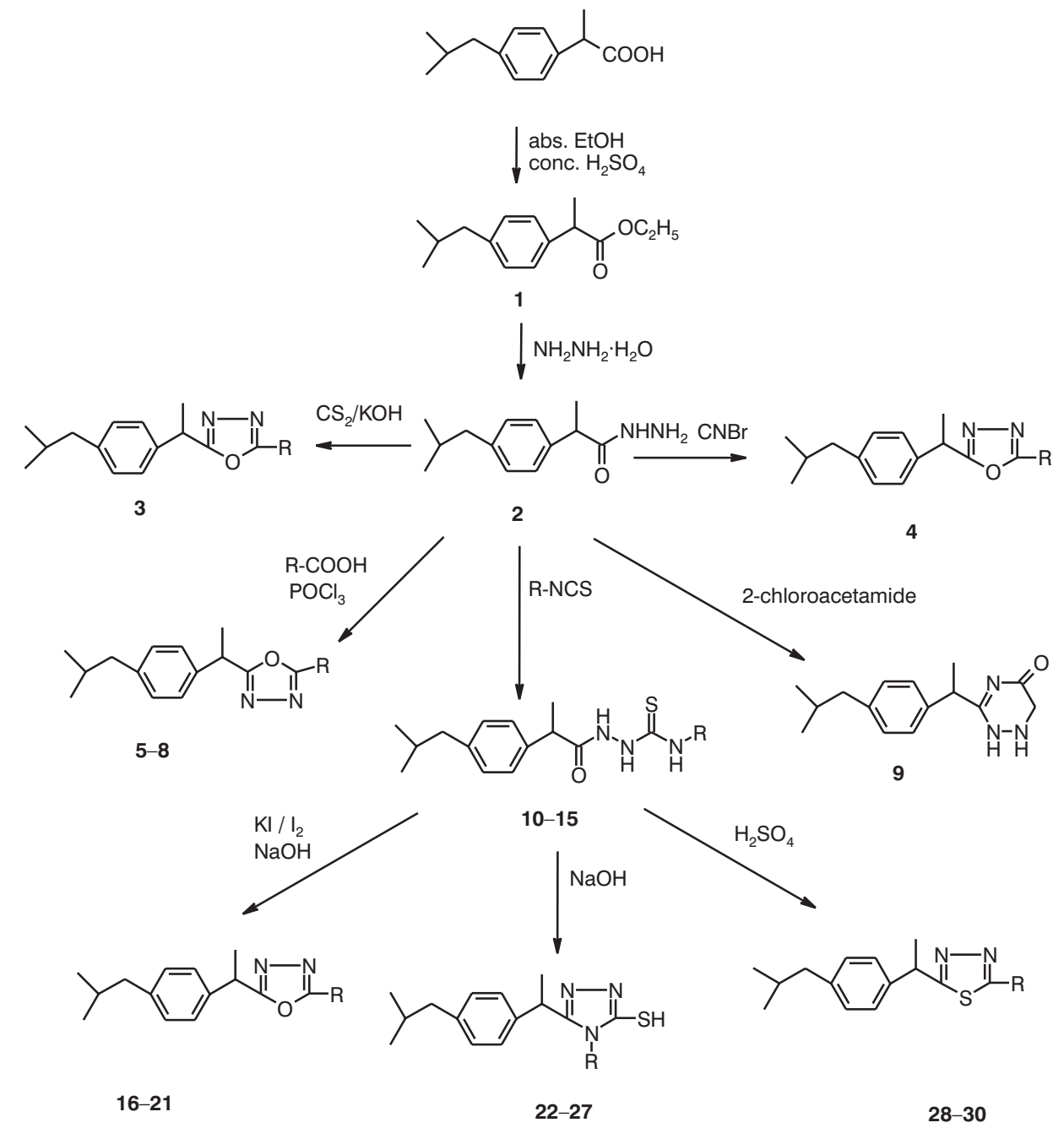

Scheme 1

5-[2-(4-i-Butylphenyl)ethyl]-2-amino-1,3,4-oxadiazole (4). - To an ethanolic solution of 2 $(0.001 \mathrm{~mol})$, cyanogen bromide $(0.001 \mathrm{~mol})$ was added. The reaction mixture was stirred with heating at $55-56{ }^{\circ} \mathrm{C}$ for $2 \mathrm{~h}$. The resulting solution was cooled and neutralized with sodium bicarbonate solution. The solid thus precipitated was filtered, washed with water, dried and recrystallized from methanol.

5-[2-(4-i-Butylphenyl)ethyl]-2-(aryl)-1,3,4-oxadiazoles (5-8). - Compound 2 (0.001 mol) and the appropriate aromatic acid $(0.001 \mathrm{~mol})$ were dissolved in phosphorus oxychloride 


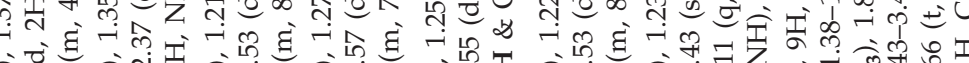

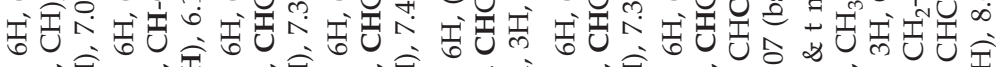

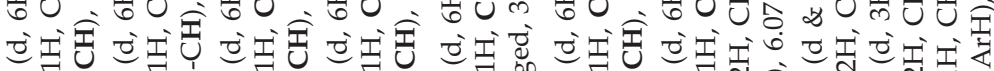
等

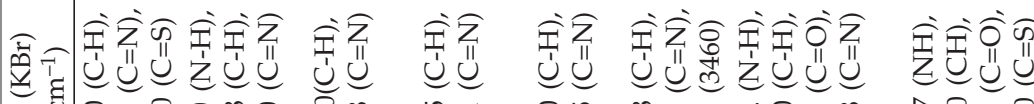

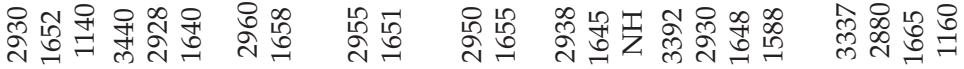

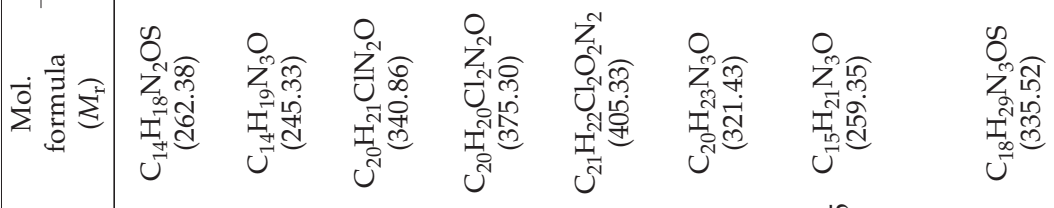

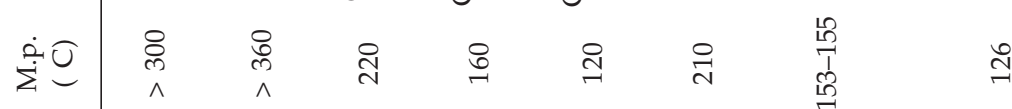
중<smiles>COc1cc(O)cc(Oc2cc(C)cc(O)c2)c1Oc1ccc(O)cc1C</smiles> 


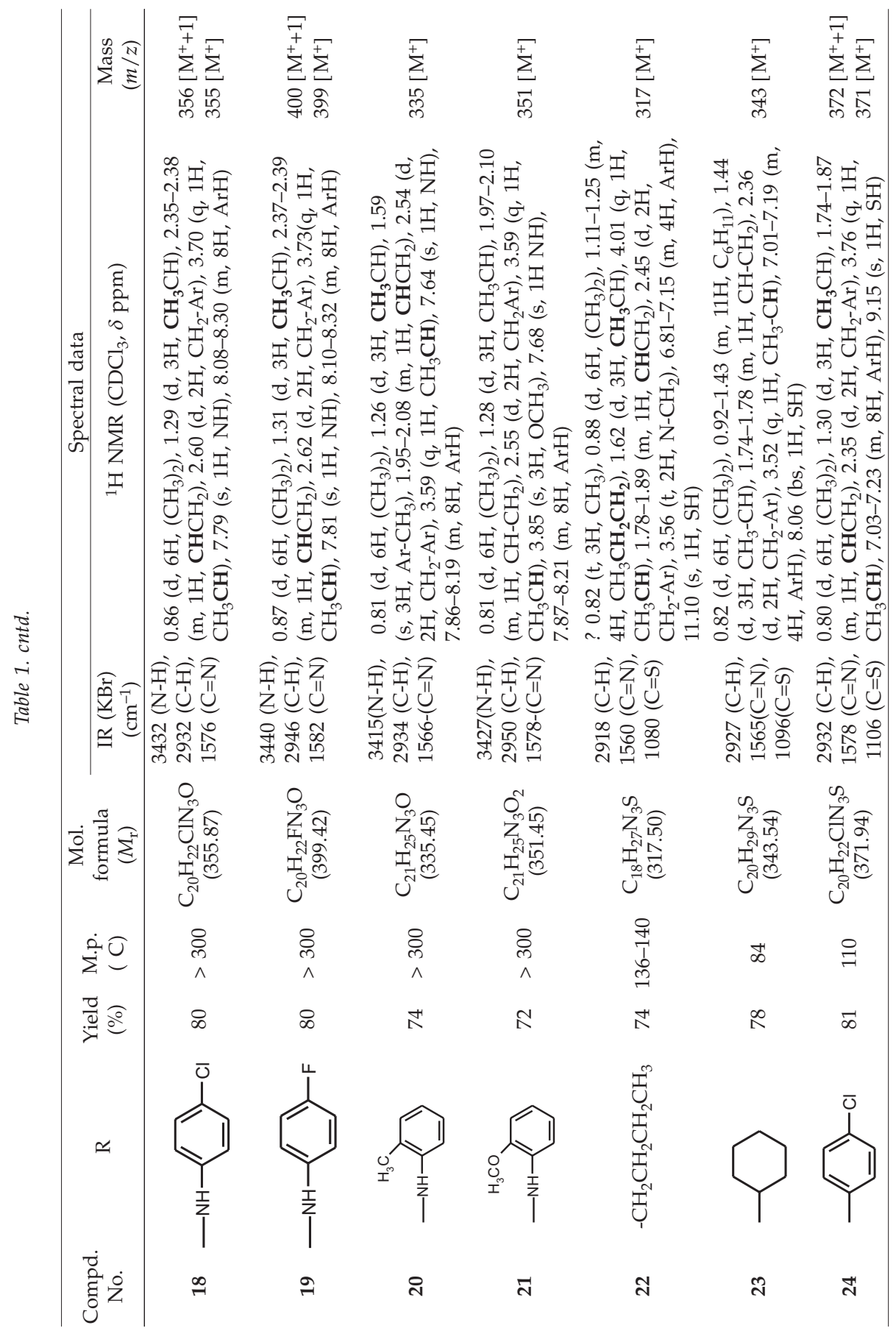




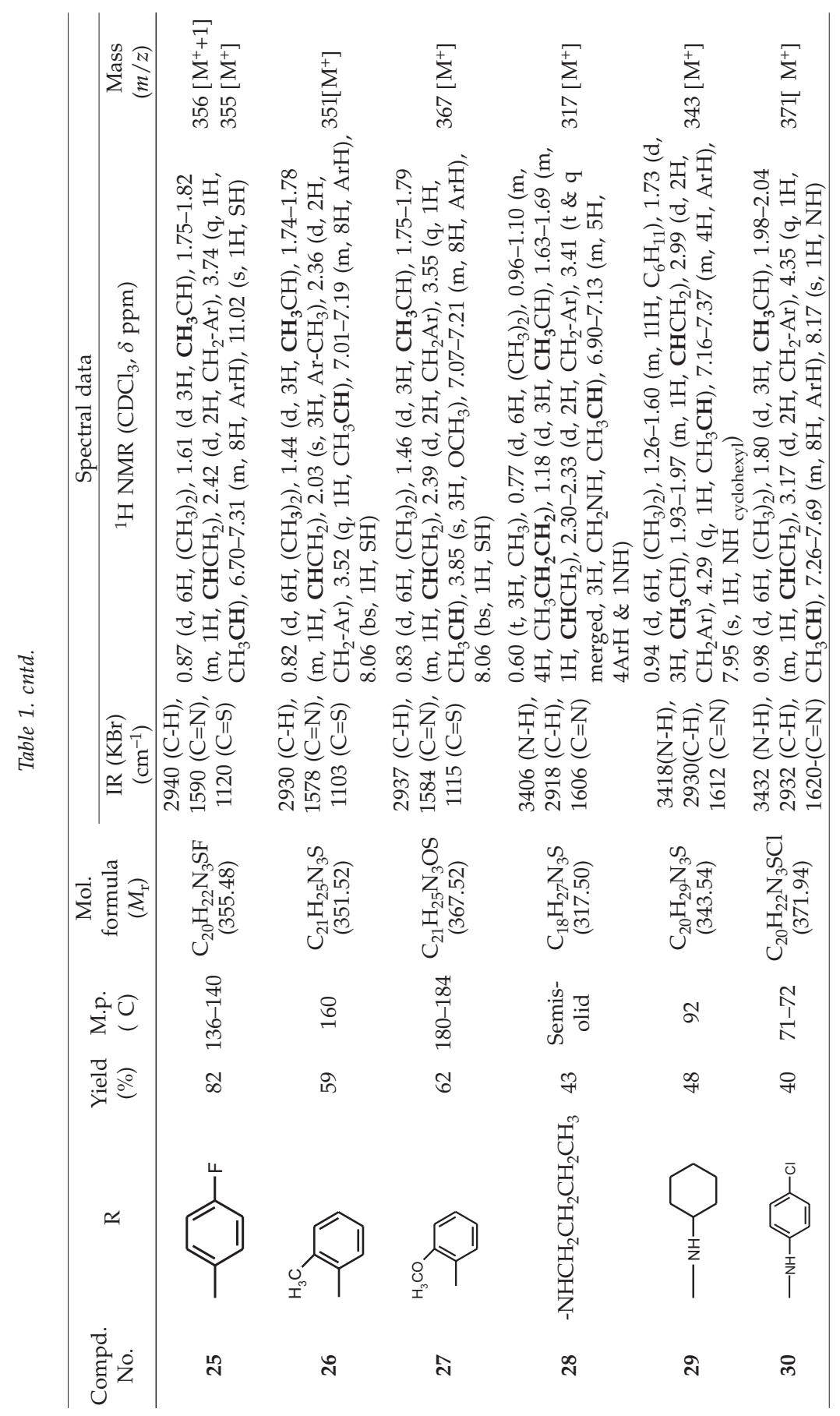


M. Amir and S. Kumar: Synthesis and evaluation of anti-inflammatory, analgesic, ulcerogenic and lipid peroxidation properties of ibuprofen derivatives, Acta Pharm. 57 (2007) 31-45.

and refluxed for 18-26 h. The reaction mixture was slowly poured over crushed ice and kept overnight. The solid thus precipitated was filtered, washed with water, dried and recrystallized from ethanol.

3-[2-(4-i-Butylphenyl) ethyl]-1,2,5,6-tetrahydro-1,2,4-triazin-5-one (9). - To compound 2 $(0.01 \mathrm{~mol})$, chloroacetamide $(0.01 \mathrm{~mol})$ and dimethylformamide $(80 \mathrm{~mL})$ were added and the reaction mixture was refluxed for $30 \mathrm{~h}$. It was then concentrated and cooled, whereupon the solid precipitated was filtered, washed with ethanol and recrystallized from $\mathrm{DMF} /$ water $(5: 1, V / V)$.

$N^{1}$-[2-(4-i-Butylphenyl) propionyl] $N^{4}$-alkyl/aryl-thiosemicarbazides (10-15). - A mixture of $2(0.10 \mathrm{~mol})$, alkyl/aryl $i$-thiocyanate $(0.10 \mathrm{~mol})$ and ethanol $(50 \mathrm{~mL})$ was refluxed on a steam bath for $10 \mathrm{~h}$. It was then concentrated, cooled and kept overnight in refrigerator. The solid thus precipitated was filtered, washed with ethanol, dried and recrystallized from ethanol.

5-[2-(4-i-Butylphenyl)ethyl]-2-alkyl/aryl-amino-1,3,4-oxadiazoles (16-21). - A suspension of 10-15 $(0.002 \mathrm{~mol})$ in ethanol $(50 \mathrm{~mL})$ was dissolved in aqueous sodium hydroxide (5 mol L ${ }^{-1}, 1 \mathrm{~mL}$ ) under cooling and stirring, resulting in a clear solution. To this, iodine in potassium iodide solution (5\%) was added gradually under stirring till the iodine colour persisted at room temperature. The reaction mixture was then refluxed for 4-6 h on a water bath. It was then cooled and poured over crushed ice. The solid mass that was precipitated was filtered, dried and recrystallized from ethanol.

5-[2-(4-i-Butylphenyl)ethyl]-4-alkyl/aryl-3-mercapto-1,2,4(H)-triazoles (22-27). - A suspension of 10-15 $(0.002 \mathrm{~mol})$ in ethanol $(25 \mathrm{~mL})$ was dissolved in aqueous sodium hydroxide $(4 \mathrm{~mol} \mathrm{~L}-1,2 \mathrm{~mL})$ and gently refluxed for $6-8 \mathrm{~h}$. The resulting solution was concentrated, cooled and filtered. The filtrate was adjusted to $\mathrm{pH} 5-6$ with diluted acetic acid and was kept aside for $1 \mathrm{~h}$. The crystals produced were filtered, washed with water, dried and recrystallized from ethanol.

5-[2-(4-i-Butylphenyl)ethyl]-2-alkyl/aryl-amino-1,3,4-thiadiazoles (28-30). - Thiosemicarbazide 10-15 (0.001 mol) was added gradually under stirring to cooled concentrated sulphuric acid $(10 \mathrm{~mL})$ for 10 minutes. The reaction mixture was further stirred for another $2-4 \mathrm{~h}$ in an ice bath. It was then poured over crushed ice under stirring. The solid precipitated was filtered, washed with water, dried and recrystallized with methanol.

\section{Pharmacology}

Wistar rats and albino mice used in the present study were housed and kept in accordance with the Hamdard University Animal Care Unit, which applies the guidelines and rules laid down by the Committee for the Purpose of Control and Supervision of Experiments on Animals (CPCSEA), Ministry of Social Justice and Empowerment, Government of India. Wistar rats and albino mice of either sex (Hamdard University, Animal House, New Delhi, India), weighing 180-200 g (12 weeks) and 22-25 g (8 weeks), were used. The animals were housed in groups of six and acclimatized to room conditions for at least 2 days before the experiments. Food and water were freely available up to the time of experiments. The food was withdrawn on the day before the experiment, but free access to water was allowed. 
All the compounds (70 $\mathrm{mg} \mathrm{kg}^{-1}$ body mass) and the reference NSAID ibuprofen (70 $\mathrm{mg} \mathrm{kg}^{-1}$ body mass) were suspended in $1 \%$ carboxymethyl cellulose (CMC) and administered orally using an animal feeding needle. The control groups received appropriate volumes of vehicle ( $1 \% \mathrm{CMC}$, oral) only.

Anti-inflammatory activity. - This activity was performed by the following procedure of Winter et al. (13) on groups of six animals each. A freshly prepared suspension of carrageenin $(1.0 \% \mathrm{~m} / \mathrm{V}, 0.1 \mathrm{~mL})$ was injected in the plantar region of the right hind paw of each rat. One group was kept as control and the animals of the other group were pretreated with the test drugs ( $70 \mathrm{mg} \mathrm{kg}^{-1}$ body mass) suspended in $1.0 \% \mathrm{CMC}$ given orally $1 \mathrm{~h}$ before the carrageenin treatment. The volume was measured before and after $4 \mathrm{~h}$ of carrageenin treatment using a pleythysmometer.

Analgesic activity. - Mice were kept individually in the test cage before acetic acid injection and habituated for 30 minutes. Screening of analgesic activity was performed after p.o. administration of test drugs at a dose of $70 \mathrm{mg} \mathrm{kg}^{-1}$ body mass. The compounds, which exhibited good anti-inflammatory activity comparable to that of ibuprofen, were screened for analgesic activity. All compounds were dissolved in 1.0\% CMC solution. One group was kept as control and received p.o. 1\% CMC. After $1 \mathrm{~h}$ of drug administration, $0.10 \mathrm{~mL}$ of $1 \%$ acetic acid solution was given to mice intraperitoneally. The acetic acid induced writhing test (14) showed stretching movements involving arching of the back, elongation of the body and extension of hind limbs which were counted for 5-15 minutes of acetic acid injection.

Acute ulcerogenesis. - Acute ulcerogenesis test was done according to Cioli et al. (15). Wistar rats were divided into different groups consisting of six animals each. Ulcerogenic activity was evaluated after p.o. administration of test compounds or ibuprofen at the dose of $200 \mathrm{mg} \mathrm{kg}^{-1}$ body mass. Control rats received p.o. the vehicle (suspension of $1 \%$ methylcellulose). Food but not water was removed $24 \mathrm{~h}$ before administration of the test compounds. After the drug treatment, the rats were fed normal diet for $17 \mathrm{~h}$ and were then sacrificed. The stomach was removed and opened along the greater curvature, washed with distilled water and cleaned gently by dipping in saline. The mucosal damage was examined by means of a magnifying glass. For each stomach the mucosal damage was assessed according to the following scoring system: 0.5 redness; 1.0 spot ulcers; 1.5 hemorrhagic streaks; 2.0 ulcers $>3$ but $\leq 5 ; 3.0$ ulcers $>5$.

The mean score of each treated group minus the mean score of control group was regarded as the severity index of gastric mucosal damage.

Lipid peroxidation. - Lipid peroxidation in the gastric mucosa was determined according to the method of Ohkawa et al. (16). After screening for ulcerogenic activity, the gastric mucosa was scraped with two glass slides, weighed $(100 \mathrm{mg})$ and homogenized in $1.8 \mathrm{~mL}$ of $1.15 \%$ ice cold $\mathrm{KCl}$ solution. The homogenate was supplemented with $0.2 \mathrm{~mL}$ of $8.1 \%$ sodium dodecyl sulfate (SDS), $1.5 \mathrm{~mL}$ of acetate buffer $(\mathrm{pH}=3.5)$ and $1.5 \mathrm{~mL}$ of $0.8 \%$ thiobarbituric acid (TBA). The mixture was heated at $95{ }^{\circ} \mathrm{C}$ for 60 minutes. After cooling, the reactants were supplemented with $5 \mathrm{~mL}$ of the mixture of $n$-butanol/pyridine $(15: 1 \mathrm{~V} / \mathrm{V})$, shaken vigorously for 1 minute and centrifuged for 10 minutes at 4000 rpm. The supernatant organic layer was taken out and absorbance was measured at 532 $\mathrm{nm}$ on a UV spectrophotometer. The results were expressed as nmol malondialdehyde (MDA) per $100 \mathrm{mg}$ tissue, using a molar absorption coefficient of $1.56 \times 10^{5} \mathrm{~cm}^{-1} \mathrm{~mol}^{-1}$ (17). 
M. Amir and S. Kumar: Synthesis and evaluation of anti-inflammatory, analgesic, ulcerogenic and lipid peroxidation properties of ibuprofen derivatives, Acta Pharm. 57 (2007) 31-45.

All the pharmacological data are expressed as mean \pm SEM; Student's $t$-test was applied to determine the significance of the difference between the control group and groups of animals treated with the test compounds.

\section{RESULTS AND DISCUSSION}

The acid hydrazide 2 was prepared by esterification of 2-(4-i-butylphenyl) propionic acid followed by treatment with hydrazine hydrate in absolute ethanol. The reaction of hydrazide 2 with carbon disulphide in alkaline medium afforded, after acidic treatment, 5-[2-(4-i-butylphenyl)ethyl]-2-mercapto-1,3,4-oxadiazole (3). The IR spectrum of compound 3 revealed the presence of absorption bands at $1140 \mathrm{~cm}^{-1}$ for $C=S$ group and at 1652 $\mathrm{cm}^{-1}$ due to $\mathrm{C}=\mathrm{N}$ stretching vibrations. Also, the ${ }^{1} \mathrm{H}$ NMR spectrum of 3 showed a singlet at $\delta 10.53 \mathrm{ppm}$ for the SH proton, confirming the formation of a mercapto triazole ring. The mass spectra showed the molecular ion peak $\mathrm{M}^{+}$at $m / z 262$ corresponding to the molecular formula $\mathrm{C}_{14} \mathrm{H}_{18} \mathrm{~N}_{2} \mathrm{OS}$. Treatment of hydrazide with cyanogen bromide afforded 5-[2-(4-i-butylphenyl)ethyl]-2-amino-1,3,4-oxadiazole (4). The IR spectrum of compound 4 showed absorption peaks at $1640 \mathrm{~cm}^{-1}$ due to $\mathrm{C}=\mathrm{N}$ stretching vibrations. Also, the ${ }^{1} \mathrm{H}$ NMR spectrum of compounds is in agreement with its structure, which revealed a singlet at $\delta 6.17$ due to the $\mathrm{NH}_{2}$ proton attached to the $2^{\text {nd }}$ position of oxadiazole ring. The mass spectra showed the molecular ion peak $\mathrm{M}^{+}$at $\mathrm{m} / \mathrm{z} 245$ corresponding to the molecular formula $\mathrm{C}_{14} \mathrm{H}_{19} \mathrm{~N}_{3} \mathrm{O}$. Various 2-aryl-1,3,4-oxadiazoles 5-8 were prepared by treatment of hydrazide with appropriate aromatic acids in the presence of phosphorus oxychloride. The structure of oxadiazole 8 was established by its IR spectrum, which showed an absorption peak at $1645 \mathrm{~cm}^{-1}$ due to $\mathrm{C}=\mathrm{N}$ stretching vibrations. The compound ${ }^{1} \mathrm{H}$ NMR spectra displayed a singlet at $\delta 6.59$ attributed to $\mathrm{NH}_{2}$ protons and a multiplet at $\delta$ 7.33-7.68 for $8 \mathrm{ArH}$ protons. The mass spectra showed the molecular ion peak $\mathrm{M}^{+}$at $\mathrm{m} / \mathrm{z}$ 321 corresponding to the molecular formula $\mathrm{C}_{20} \mathrm{H}_{23} \mathrm{~N}_{3} \mathrm{O}$. 3-[2-(4-i-Butylphenyl)ethyl]-1,2,5,6-tetrahydro-1,2,4-triazine-5-one (9) was prepared by condensation of hydrazide with chloroacetamide. The structure of compound was confirmed by appearance of absorption peaks at $1588 \mathrm{~cm}^{-1}$ due to $C=N$ and $1648 \mathrm{~cm}^{-1}$ corresponding to $\mathrm{C}=\mathrm{O}$ group. The ${ }^{1} \mathrm{H}$ NMR spectrum of compounds showed a singlet at $\delta 2.43 \mathrm{ppm}$ for $\mathrm{CH}_{2}$ proton of triazinone ring. The presence of two broad singlets at $\delta 5.38$ and $6.07 \mathrm{ppm}$ for NH protons also confirms the formation of the compound. The mass spectra of compound 9 showed molecular ion peak $\mathrm{M}^{+}$at $m / z 259$ corresponding to molecular formula $\mathrm{C}_{15} \mathrm{H}_{21} \mathrm{~N}_{3} \mathrm{O}$.

Furthermore, hydrazide 2 on treatment with various alkyl/aryl $i$-thiocyanates gave $N^{1}$-[2-(4-i-butylphenyl)propionyl]- $N^{4}$-alkyl/arylthiosemicarbazides (10-15). The structure of thiosemicarbazide $\mathbf{1 0}$ was confirmed by its IR spectrum, which displayed absorption bands at $3337 \mathrm{~cm}^{-1}$ for $\mathrm{NH}, 1665 \mathrm{~cm}^{-1}$ due to $\mathrm{C}=\mathrm{O}$ and $1160 \mathrm{~cm}^{-1}$ corresponding to $\mathrm{C}=\mathrm{S}$ stretch vibrations. The ${ }^{1} \mathrm{H}$ NMR spectrum showed a multiplet at $\delta 7.11-7.26 \mathrm{ppm}$ for $4 \mathrm{ArH}$ protons. The CSNH and $\mathrm{CONH}$ protons were observed as a singlet at $\delta 8.62$ and $9.04 \mathrm{ppm}$, respectively, confirming the formation of thiosemicarbazide. The mass spectra showed molecular ion peak $\mathrm{M}^{+}$at $\mathrm{m} / z 335$ corresponding to molecular formula $\mathrm{C}_{18} \mathrm{H}_{29} \mathrm{~N}_{3} \mathrm{OS}$. 
M. Amir and S. Kumar: Synthesis and evaluation of anti-inflammatory, analgesic, ulcerogenic and lipid peroxidation properties of ibuprofen derivatives, Acta Pharm. 57 (2007) 31-45.

The thiosemicarbazides were oxidatively cyclised to 2-alkyl/arylamino-5-substituted-1,3,4-oxadiazoles (16-21) by elimination of $\mathrm{H}_{2} \mathrm{~S}$ using iodine and potassium iodide in ethanolic sodium hydroxide. The IR spectrum of oxadiazole $\mathbf{1 6}$ showed absorption peak at $1560 \mathrm{~cm}^{-1}$ due to $\mathrm{C}=\mathrm{N}$ stretch vibration. The structure was further supported by its ${ }^{1} \mathrm{H}$ NMR spectrum, which showed a multiplet at $\delta 6.91-7.15$ ppm for 4 ArH and 1 NH protons. The mass spectra showed molecular ion peak $\mathrm{M}^{+}$at $m / z 301$ corresponding to molecular formula $\mathrm{C}_{18} \mathrm{H}_{27} \mathrm{~N}_{3} \mathrm{O}$. The thiosemicarbazides $\mathbf{1 0 - 1 5}$ on heating with $4 \mathrm{~mol} \mathrm{~L}^{-1}$ $\mathrm{NaOH}$ in ethanol underwent smooth cyclisation through dehydration to afford 5-substituted-4-alkyl/aryl-3-mercapto-4H-1,2,4-triazoles (22-27). The structure of triazole 22 was confirmed by its IR spectrum, which displayed absorption peak at $1560 \mathrm{~cm}^{-1}$ due to $\mathrm{C}=\mathrm{N}$ and at $1080 \mathrm{~cm}^{-1}$ corresponding to $\mathrm{C}=\mathrm{S}$ group. The formation of triazole ring was further supported by its ${ }^{1} \mathrm{H}$ NMR spectrum, which showed a triplet for $\mathrm{NCH}_{2}$ proton at $\delta$ $3.56 \mathrm{ppm}$. A singlet for SH proton was also observed at $\delta 11.10 \mathrm{ppm}$. The mass spectra of the compound 22 showed molecular ion peak $\mathrm{M}^{+}$at $\mathrm{m} / \mathrm{z} 317$ corresponding to molecular formula $\mathrm{C}_{18} \mathrm{H}_{27} \mathrm{~N}_{3} \mathrm{~S}$. 2-Alkyl/arylamino-5-substituted-1,3,4-thiadiazoles (28-30) were obtained by cyclisation of $\mathbf{1 0 - 1 5}$ by treating with cold concentrated sulphuric acid. The IR spectrum of compound 30 showed absorption peak at $1620 \mathrm{~cm}^{-1}$ due to $\mathrm{C}=\mathrm{N}$ stretching vibration. In the ${ }^{1} \mathrm{H}$ NMR spectrum of the compound the singlet of $\mathrm{CSNH}$ and $\mathrm{CONH}$ of thiosemicarbazide disappeared and a multiplet was obtained in the aromatic region at $\delta$ 7.26-7.69 ppm for 8 ArH protons. The $\mathrm{NH}$ proton was observed as a singlet at $\delta 8.17$ confirming he structure of compound. The mass spectra of the compound 30 showed molecular ion peak $\mathrm{M}^{+}$at $m / z 371$ corresponding to molecular formula $\mathrm{C}_{20} \mathrm{H}_{22} \mathrm{ClN}_{3} \mathrm{~S}$.

The anti-inflammatory activity of the synthesized compounds 3, 4, 7, 9, 16-19, 21-24, 27-30 were evaluated by the carrageenin induced paw edema method. The compounds were tested at an oral dose of $70 \mathrm{mg} \mathrm{kg}^{-1}$ body mass and were compared with the standard drug ibuprofen at the same oral dose. The tested compounds showed anti-inflammatory activity ranging from 50 to $86 \%$ (Table II), and the standard drug ibuprofen showed $92 \%$ inhibition after 4 hours. The oxadiazole derivative 16 having an $n$-butyl amino group showed the maximum activity $(86 \%)$, whereas when this group was replaced by the cyclohexyl amino group 17 the activity was found to be minimal $(50 \%)$. It was observed that oxadiazole derivatives having $p$-chlorophenyl amino, $o$-methoxyphenyl amino and 2,4-dichloromethoxyphenyl groups at the $2^{\text {nd }}$ position showed high activity $(85,79$ and $82 \%)$, respectively. When these groups were replaced by $p$-fluorophenyl amino (19), 2mercapto (3) and 2-amino (4) groups, the activity was found to be reduced.

The 1,2,4-triazole derivatives of ibuprofen showed anti-inflammatory activity ranging from 68 to $82 \%$. The highest activity was found for the triazole derivatives 22 and 27 $(82 \%)$, having the $n$-butyl group and $o$-methoxyphenyl group at position 4 . When these groups were replaced by the cyclohexyl group in compound 23, the activity was found to be minimal $(68 \%)$. The triazole derivative 24 having the $p$-chlorophenyl group showed moderate activity.

The 1,3,4-thiadiazole derivatives of ibuprofen showed anti-inflammatory activity ranging from 75 to $84 \%$. Maximum activity was shown by the thiadiazole derivative $\mathbf{3 0}$ having the $p$-chlorophenyl amino group at position 2 . When this group was replaced by the $n$-butyl amino group in derivative 28 , the activity was found to be decreased (75\%), whereas in case of oxadiazole and triazole derivatives the compound having the $n$-butyl group 
M. Amir and S. Kumar: Synthesis and evaluation of anti-inflammatory, analgesic, ulcerogenic and lipid peroxidation properties of ibuprofen derivatives, Acta Pharm. 57 (2007) 31-45.

Table II. Biological data of ibuprofen derivatives ${ }^{a}$

\begin{tabular}{|c|c|c|c|c|c|c|c|}
\hline $\begin{array}{c}\text { Compd. } \\
\text { No. }\end{array}$ & $\begin{array}{c}\text { Dose } \\
\left(\mathrm{mg} \mathrm{kg}^{-1},\right. \\
1 \% \mathrm{CMC})\end{array}$ & $\begin{array}{l}\text { Anti-inflamma- } \\
\text { tory activity } \\
\text { (mean inhibition } \\
\pm \text { SEM \%) }\end{array}$ & $\begin{array}{c}\text { Dose } \\
\left(\mathrm{mg} \mathrm{kg}^{-1}\right. \\
1 \% \mathrm{CMC})\end{array}$ & $\begin{array}{l}\text { Analgesic } \\
\text { activity (mean } \\
\text { inhibition } \pm \\
\text { SEM, \%) }\end{array}$ & $\begin{array}{c}\text { Dose } \\
\left(\mathrm{mg} \mathrm{kg}^{-1}\right. \\
1 \% \mathrm{CMC})\end{array}$ & $\begin{array}{c}\text { Ulcerogenic } \\
\text { activity } \\
\text { (mean severity } \\
\text { index } \pm \text { SEM) }\end{array}$ & $\begin{array}{l}\text { MDA (mean } \\
\pm \text { SEM, mol } \\
\text { per } 100 \mathrm{mg} \\
\text { tissue) }\end{array}$ \\
\hline Control & & - & & - & & $0.0 \pm 0.0^{\mathrm{b}}$ & $3.37 \pm 0.01^{b}$ \\
\hline 3 & 70 & $69 \pm 3.0^{b}$ & - & - & - & - & - \\
\hline 4 & 70 & $75 \pm 1.7^{\mathrm{b}}$ & & - & - & - & - \\
\hline 7 & 70 & $82 \pm 1.7^{c}$ & 70 & $57 \pm 0.9^{\mathrm{b}}$ & 200 & $0.6 \pm 0.1^{\mathrm{c}}$ & $3.96 \pm 0.15^{c}$ \\
\hline 9 & 70 & $71 \pm 5.0^{\mathrm{d}}$ & - & - & - & - & - \\
\hline 16 & 70 & $86 \pm 1.7^{e}$ & 70 & $73 \pm 0.9^{b}$ & 200 & $0.5 \pm 0.2^{b}$ & $3.85 \pm 0.14^{\mathrm{b}}$ \\
\hline 17 & 70 & $50 \pm 3.0^{\mathrm{b}}$ & - & - & - & - & - \\
\hline 18 & 70 & $85 \pm 1.9^{e}$ & 70 & $59 \pm 0.5^{b}$ & 200 & $0.8 \pm 0.2^{\mathrm{d}}$ & $4.26 \pm 0.15^{\mathrm{d}}$ \\
\hline 19 & 70 & $71 \pm 2.6^{b}$ & - & - & - & - & - \\
\hline 21 & 70 & $79 \pm 0.8^{b}$ & - & - & & - & - \\
\hline 22 & 70 & $82 \pm 0.9^{b}$ & 70 & $71 \pm 1.2^{\mathrm{b}}$ & 200 & $0.6 \pm 0.2^{c}$ & $3.99 \pm 0.15^{c}$ \\
\hline 23 & 70 & $68 \pm 2.7^{b}$ & - & - & - & - & - \\
\hline 24 & 70 & $76 \pm 2.1^{b}$ & - & - & - & - & - \\
\hline 27 & 70 & $82 \pm 2.0^{\mathrm{d}}$ & - & - & - & - & - \\
\hline 28 & 70 & $75 \pm 2.0^{\mathrm{b}}$ & - & - & - & - & - \\
\hline 29 & 70 & $76 \pm 3.0^{c}$ & - & - & - & - & - \\
\hline 30 & 70 & $84 \pm 2.0^{\mathrm{d}}$ & 70 & $56.6 \pm 1.1^{\mathrm{b}}$ & 200 & $0.5 \pm 0.0^{b}$ & $3.80 \pm 0.10^{b}$ \\
\hline Ibuprofen & 70 & $92 \pm 1.0$ & 70 & $83.5 \pm 0.7^{\mathrm{b}}$ & 200 & $1.8 \pm 0.2$ & $5.05 \pm 0.14$ \\
\hline
\end{tabular}

a $n=6$.

Anti-inflammatory and analgesic activities of the test compounds were measured with respect to the control and compared with respect to the standard drug; ulcerogenic and lipid peroxidation were compared with respect to standard drug.

${ }^{\mathrm{b}} p<0.0001,{ }^{\mathrm{c}} p<0.001, \mathrm{~d} p<0.05$.

showed highest activity. When the hydrazide of ibuprofen was treated with 2-chloroacetamide, 1,2,4-triazine derivative was obtained, which also showed significant anti-inflammatory activity $(71 \%)$.

The compounds that showed anti-inflammatory activity higher than $80 \%$ were tested for analgesic activity. Compounds 7, 16, 18, 22 and 30 showed analgesic activity ranging from 57 to $73 \%$, whereas the standard drug ibuprofen showed $84 \%$ at a $70 \mathrm{mg} \mathrm{kg}^{-1}$ oral dose. Among all the tested compounds, the oxadiazole derivative having the $n$-butyl amino group 16 showed maximum activity (73\%). When this group was replaced by the $p$-chlorophenyl amino (18) and 2,4-dichloromethoxyphenyl group (7), there was a significant decrease in the activity. Among all the tested compounds, thiadiazole 30 showed minimum activity (57\%), whereas triazole derivative 22 showed significant analgesic activity $(71 \%)$. 
The compounds that were screened for analgesic activity were further screened for their ulcerogenic activity. All the compounds were tested at an oral dose of $200 \mathrm{mg} \mathrm{kg}^{-1}$ body mass. The maximum reduction in ulcerogenic activity (mean severity index \pm SEM, $n=6$ ) was $0.5 \pm 0.2$ ), found in oxadiazole derivative 16 , having the $n$-butyl amino group at position 2 . In thiadiazole derivative, maximum reduction $(0.5 \pm 0)$ was found in compound 30, having the $p$-chlorophenyl amino group, whereas the same group present in oxadiazole derivative 18 showed the maximum severity index $(0.8 \pm 0.2)$. The other two compounds, 7 and 22, oxadiazole and triazole derivatives, respectively, showed moderate severity indexes. The standard drug ibuprofen showed a high severity index of $1.8 \pm$ 0.2 .

It has been reported in the literature that lower ulcerogenic activity of compounds is combined with a reduced malondialdehyde (MDA) content in the affected area of the gastrointestinal tract, end products of lipid peroxidation $(\mathbf{1 8}, \mathbf{1 9})$. Therefore, an attempt was made to correlate the decrease in ulcerogenic activity of the compounds with that of lipid peroxidation. All the compounds screened for ulcerogenic activity were also analyzed for lipid peroxidation. Lipid peroxidation is measured as nmol of MDA per 100 mg of gastric mucosa tissue. The ibuprofen (standard drug) showed the highest lipid peroxidation $(5.05 \pm 0.14)$, whereas the control group showed $3.37 \pm 0.01$. It was found that all the cyclized derivatives showing less ulcerogenic activity also showed a reduction in lipid peroxidation (Table II). Thus, these studies show that synthesized compounds have inhibited the induction of gastric mucosal lesions and the results further suggested that their protective effect might be related to the inhibition of lipid peroxidation in the gastric mucosa.

\section{CONCLUSIONS}

Various oxadiazole, triazole, thiadiazole and triazine derivatives of ibuprofen were prepared with the objective of developing better anti-inflammatory molecules with minimal ulcerogenic activity. Among these, an oxadiazole derivative of ibuprofen, 5-[2-(4-ibutylphenyl) ethyl]- $n$-butyl amino-1,3,4-oxadiazole derivative showed maximum activity $(86 \%)$. It also showed maximum analgesic activity, maximum reduction of the severity index along with minimum lipid peroxidation.

Acknowledgements. - The financial support from the University Grants Commission (U.G.C.) Research Project (Project Number: F-19/01 (SR-I), UGC) is gratefully acknowledged. The authors also thank the Director of the Central Drug Research Institute (CDRI) Lucknow for providing the ${ }^{1} \mathrm{H}$ NMR and mass spectra of compounds.

\section{REFERENCES}

1. M. B. Kimmey, NSAID, ulcers and prostaglandins, J. Rheumatol. 19 (1992) 68-73.

2. C. J. Smith, Y. Zhang, C. M. Koboldt, J. Muhammad, B. S. Zwefel, A. Shaffer, J. J. Talley, J. L. Masferrer, K. Serbert and P. C. Isakson, Pharmacological analysis of cyclo-oxygenase-1 in inflammation, Proc. Natl. Acad. Sci. USA 95 (1998) 13313-13318. 
3. C. Hawkey, L. Laine, T. Simon, A. Beaulieu, J. Maldonado-Cocco, E. Acevedo, A. Shahane, H. Quan, J. Bolognese and E. Mortensen, Comparison of the effect of rofecoxib, ibuprofen and placebo on the gastroduodenal mucosa of patients with osteoarthritis: A randomized, double blind, placebo-controlled trial, Arthritis Rheum. 43 (2000) 370-377.

4. T. D. Warner, F. Giuliano, I. Vaynovie, A. Bukasa, J. A. Mitchell and J. R. Vave, Non-steroid drug selectivities for cyclo-oxygenase- 1 rather than cyclo-oxygenase- 2 are associated with human gastro-intestinal toxicity: A full in vitro analysis, Proc. Natl. Acad. Sci. USA 96 (1999) 7563-7568.

5. F. L. Lanza, A guideline for the treatment and prevention of NSAID-induced ulcers, Am. J. Gastroenterol. 93 (1998) 2037-2046.

6. A. S. Kalgutkar, A. B. Marnett, B. C. Crews, R. P. Remmel and L. J. Marnett, Ester and amide derivatives of the nonsteroidal antiinflammatory drug, indomethacin, as selective cyclo-oxygenase-2 inhibitor, J. Med. Chem. 43 (2000) 2860-2870.

7. M. Duflos, M. R. Nourrisson, J. Brelet, J. Courant, G. Le Baut, N. Grimaud and J. Y. Petit, N-Pyridinyl-indole-3-(alkyl) carboxamides and derivatives as potential systemic and topical inflammation inhibitors, Eur. J. Med. Chem. 36 (2001) 545-553.

8. M. Amir and S. Kumar, Anti-inflammatory and gastro sparing activity of some new indomethacin derivatives, Arch. Pharm. Chem. Life Sci. 338 (2005) 24-31.

9. F. A. Omar, N. M. Mahfouz and M. A. Rahman, Design, synthesis and anti-inflammatory activity of some 1,3,4-oxadiazole derivatives, Eur. J. Med. Chem. 31 (1996) 819-825.

10. M. Amir, A. Oberoi and S. Alam, Synthesis and anti-inflammatory activity of some new 6-methoxy- $\alpha$-methyl-2-naphthalene acetic acid derivatives, Indian J. Chem. 38B (1999) 237-239.

11. E. Palaska, G. Sahin, P. Kelicen, N. T. Durlu and G. Altinok, Synthesis and anti-inflammatory activity of 1-acylthiosemicarbazide: 1,3,4-oxadiazoles, 1,3,4-thiadiazoles and 1,2,4-triazole-3-thiones, Farmaco 57 (2002) 101-107.

12. B. Furniss, A. H. Hannaford, P. W. G. Smith and A. R. Tatchell, Vogel's Text Book of Practical Organic Chemistry, 5th ed., Addison Wesley Longman, New Delhi 1998, pp. 1077.

13. C. A. Winter, E. A. Risley and G. N. Nuss, Carrageenin-induced edema in hind paw of the rat as an assay for anti-inflammatory drugs, Proc. Soc. Exp. Biol. 111 (1962) 544-547.

14. A. Kumar, D. Bansal, K. Bajaj, S. Sharma, Archana and V. K. Srivastava, Synthesis of some newer derivatives of 2-amino benzoic acid as potent anti-inflammatory and analgesic agents, Bioorg. Med. Chem. 11 (2003) 5281-5291.

15. V. Cioli, S. Putzolu, V. Rossi, P. Sorza Barcellona and C. Corradino, The role of direct tissue contact in the production of gastro-intestinal ulcers by anti-inflammatory drugs in rats, Toxicol. Appl. Pharmacol. 50 (1979) 283-289.

16. H. Ohkawa, N. Ohishi and K. Yagi, Assay for lipid peroxides in animal tissues by thiobarbituric acid reaction, Anal. Biochem. 95 (1979) 351-358.

17. B. Galunska, K. Marazova, T. Yankova, A. Popov, P. Frangov, I. Krushkov and D. I. Massa, Effect of paracetamol and propacetamol on gastric mucosal damage and gastric lipid per oxidation caused by acetylsalicylic acid in rats, Pharmacol. Res. 46 (2002) 141-148.

18. Y. Naito, T. Yoshikawa, N. Yoshida and M. Kondo, Role of oxygen radical and lipid peroxidation in indomethacin-induced gastric mucosal injury, Dig. Dis. Sci. 43 (Suppl. 9) (1998) 30S-34S.

19. T. Pohle, T. Brzozowski, J. C. Becker, I. R. Vander Voort, A. Markmann, S. J. Konturek, A. Moniczewski, W. Domschke and J. W. Konturek, Role of reactive oxygen metabolites in aspirin-induced gastric damage in humans, gastroprotection by vitamin, Aliment. Pharmacol. Ther. 15 (2001) $677-687$. 
M. Amir and S. Kumar: Synthesis and evaluation of anti-inflammatory, analgesic, ulcerogenic and lipid peroxidation properties of ibuprofen derivatives, Acta Pharm. 57 (2007) 31-45.

$S A \check{Z} E T A K$

\section{Sinteza i procjena protuupalnog, analgetskog i ulcerogenog djelovanja derivata ibuprofena, te njihovog učinka na peroksidaciju lipida}

MOHAMMAD AMIR i SHIKHA KUMAR

Karboksilna skupina ibuprofena prevedena je $\mathrm{u}$ peteročlane heterocikličke prstene da se smanji ulcerogeni učinak. Pripravljeni su različiti 1,3,4-oksadiazoli (3-8, 16-21), 1,2,4-triazoli (22-27), 1,3,4-tiadiazoli (28-30) i 1,2,4-triazin (9) ciklizacijom hidrazida 2-(4-i-butilfenil) propanske kiseline i $N^{\prime}$-[2-(4-i-butilfenil)propionil]- $N^{4}$-alkil/aril tiosemikarbazida (10-15) uz različite reakcijske uvjete. Heterociklički derivati ibuprofena su u testovima na protuupalno djelovanje na edem šape induciran karageninom pokazali inhibitorni učinak od 50-86\%, dok je sam ibuprofen u istoj dozi inhibirao 92\%. Spojevi koji su inhibirali edem za više od $80 \%(7,16,18$ i 22$)$ testirani su na analgetsko i ulcerogeno djelovanje, te na sposobnost peroksidacije lipida. Svi testirani spojevi imaju značajno smanjenu ulcerogenost $\mathrm{u}$ rasponu $0,5 \pm 0,0$ do $0,8 \pm 0,2$, dok je ibuprofen imao najveći indeks $1,8 \pm 0,2$. Spojevi koji su pokazali manji ulcerogeni učinak smanjivali su i produkciju malondialdehida u sluznici želuca, krajnjeg produkta peroksidacije lipida. Najjači protuupalni i analgetski učinak, a ujedno najmanju ulcerogenost i najmanju peroksidaciju lipida, pokazao je oksadiazolski derivat 16 .

Ključne riječi: derivati ibuprofena, protuupalno djelovanje, ulcerogenost, peroksidacija lipida

Department of Pharmaceutical Chemistry, Faculty of Pharmacy, Hamdard University New Delhi-110062, India 